\title{
Quinolines derivatives as promising new antifungal candidates for the treatment of candidiasis and dermatophytosis
}

\author{
Gabriella da Rosa Monte Machado ${ }^{1,2}$ (1) - Denise Diedrich ${ }^{3}$. Thaís Carine Ruaro ${ }^{3}$ - Aline Rigon Zimmer ${ }^{3}$. \\ Mário Lettieri Teixeira ${ }^{4} \cdot$ Luís Flávio de Oliveira $^{5} \cdot$ Mickael Jean $^{6}$. Pierre Van de Weghe ${ }^{6}$. \\ Saulo Fernandes de Andrade ${ }^{1,3}$. Simone Cristina Baggio Gnoatto ${ }^{3}$ - Alexandre Meneghello Fuentefria ${ }^{1,3}$
}

Received: 7 April 2020 / Accepted: 23 July 2020 / Published online: 31 July 2020

(C) Sociedade Brasileira de Microbiologia 2020

\begin{abstract}
Fungal infections have emerged as a current serious global public health problem. The main problem involving these infections is the expansion of multidrug resistance. Therefore, the prospection of new compounds with efficacy antifungal becomes necessary. Thus, this study evaluated the antifungal profile and toxicological parameters of quinolines derivatives against Candida spp. and dermatophyte strains. As a result, a selective anti-dermatophytic action was demonstrated by compound 5 (geometric means $\left.\left(\mathrm{GM}=19.14 \mu \mathrm{g} \mathrm{ml}^{-1}\right)\right)$. However, compounds $2\left(\mathrm{GM}=50 \mu \mathrm{g} \mathrm{ml}^{-1}\right)$ and $3\left(\mathrm{GM}=47.19 \mu \mathrm{g} \mathrm{ml}^{-1}\right)$ have presented only antiCandida action. Compounds 3 and 5 did not present cytotoxic action. Compound 5 did not produce dermal and mucosal toxicity. In addition, this compound showed the absence of genotoxic potential, suggesting safety for topical and systemic use. Quinolines demonstrated a potent anti-dermatophytic and anti-yeast action. Moreover, compound 5 presented an excellent toxicological profile, acting as a strong candidate for the development of a new effective and safe compound against dermatophytosis of difficult treatment.
\end{abstract}

Keywords Candida $\cdot$ Dermatophyte $\cdot$ Antifungal potential $\cdot$ Quinoline derivatives $\cdot$ Fungal resistance

\section{Introduction}

Dermatophytosis are caused by fungi known as dermatophytes. These fungi have a strong biotropism by keratinized tissues, such as skin, hair, and nails. Thus, their ability to cause mycosis is dependent on keratin [1-3]. The incidence of

Gabriella da Rosa Monte Machado and Denise Diedrich contributed equally to this work.

Responsible Editor: Luis Henrique Souza Guimaraes

Electronic supplementary material The online version of this article (https://doi.org/10.1007/s42770-020-00348-4) contains supplementary material, which is available to authorized users.

Gabriella da Rosa Monte Machado gabbirosam@gmail.ocom

1 Postgraduate Program in Agricultural Microbiology and Environment, Federal University of Rio Grande do Sul, Sarmento Leite ${ }^{\circ}$ 500, Farroupilha, Porto Alegre, RS 90050-170, Brazil

2 Laboratory of Applied Mycology - Faculty of Pharmacy, Federal University of Rio Grande do Sul, Porto Alegre, Brazil dermatophytosis has increased over recent years, with a prevalence of $25 \%$ of the worldwide population [4-6]. Currently, they are considered the fourth most prevalent fungal infections worldwide [7]

Candida spp. yeasts are principal opportunistic fungal pathogens in humans and animals. Candida infections present
3 Postgraduate Program in Pharmaceutical Sciences, Federal University of Rio Grande do Sul, Avenue Ipiranga, n 2752 Azenha, Porto Alegre, RS 90610-000, Brazil

4 Pharmacology Laboratory, Federal Catarinense Institute, Highway SC 283 - Fragosos, Concórdia, SC 89703-720, Brazil

5 Cell Toxicology Research Laboratory, Federal University of Pampa, BR 472 - Km 585, Uruguaiana, RS 97501-970, Brazil

6 Natural Products Syntheses and Medicinal Chemistry Laboratory, Rennes University 1, Street du Thabor, 35000 Rennes, France 
worldwide occurrence and range from superficial and cutaneous candidiasis to more severe forms, such as invasive candidiasis and candidemias $[8,9]$. The incidences of these infections have increased considerably in the last years $[10,11]$. This fact is associated to the increase of the number of immunosuppressive individuals due to the HIV epidemic, chronic disease, or chemotherapies [12, 13].

The main problem involving fungal infection is the expansion of multidrug resistance [14-16]. This phenomenon is a global health problem and has led to failures in the clinical treatment and recurrence of infection, leading to increase cases of mortality $[2,17]$. In addition, antifungals currently present high rates of toxicity to the patient, at the topical or systemic levels [18-21]. From this context, new strategies to combat antifungal resistance, such as the prospection of new compounds that can overcome the limitations of currently available antifungal agents, become essential.

Quinoline nucleus plays a fundamental role in the prospection of new therapeutic compounds with broad spectrum biological action $[22,23]$. Some drugs containing the quinoline structural nucleus are commercially available, such as nitroxoline (antibacterial action), chloroquine and hydroxychloroquine (antimalarial action), and bedaquiline (multidrug-resistant tuberculosis action) [24-26]. At present, chloroquine and hydroxychloroquine have been considered a promising treatment in critical patients affected by coronavirus disease 2019 (COVID-19), current pandemic without specific therapeutic agents or vaccines and substantial mortality $[27,28]$. Moreover, a variety of pharmacological proprieties of quinoline derivatives, such as anticancer, antimalarial, antiinflammatory, antituberculosis, anti-Toxoplasma, antibacterial, and antifungal actions have been considerably related [29-38]. However, the antifungal actions of these derivatives against dermatophytic species are rare.

Considering that quinoline derivatives can be potentially active against different fungal species and present low toxicity, this study evaluated the antifungal effectiveness and toxicological parameters of quinolines derivatives against Candida and dermatophytes strains of difficult treatment.

\section{Material and methods}

Chemicals and reagents were purchased from commercial suppliers and used as directed by the manufacturer. The solvents were distilled under a nitrogen atmosphere when necessary. The reactions that required anhydrous conditions were carried out under a nitrogen or argon atmosphere. The reactions were monitored by thin layer chromatography (TLC) on $0.2 \mathrm{~mm}$ plates precoated with silica gel (Merck®) and visualized by spraying with different developers (sulfuric anisaldehyde, phosphomolybdic acid, and potassium permanganate) under heating, in addition under UV light. Evaporation and concentration of the solvents were done on the rotary evaporator using the vacuum pump. ${ }^{1} \mathrm{H}$ NMR and ${ }^{13} \mathrm{C}$ NMR spectra were measured on Bruker® $300 \mathrm{MHz}$ equipment using $\mathrm{SiMe}_{4}$ (TMS) as an internal standard. Chemical shifts $\left({ }^{\delta}\right)$ are given in ppm and the coupling constants $(\mathrm{J})$ are given in Hertz. The deuterated solvent used was $\mathrm{CDCl}_{3}$. Splitting patterns were designated as follows: $\mathrm{s}=$ simplet, $\mathrm{sl}=$ singlet extended, $\mathrm{d}=$ doublet, $\mathrm{dd}=$ doublet doublet, $\mathrm{ddd}=$ doublet doublet, $\mathrm{t}=$ triplet, $\mathrm{dt}=$ doublet triplet, $\mathrm{q}=$ quartet, and $\mathrm{m}=$ multiplet. Purifications were performed by column chromatography using silica gel 60 (70-200 mesh and 40-60 mesh) or using silica gel 60 PF254 for preparative thin layer chromatography. Petroleum ether (PE) was used in the purifications with the fraction of low boiling point (40-60).<smiles>Cc1ccnc2ccc(Br)cc12</smiles>

\section{Synthesis of 6-bromo 4-methylquinoline (1)}

In the reaction tube, 1 eq. $(0.5 \mathrm{mMol}, 86 \mathrm{mg})$ of 4 bromoaniline and 1 eq. $(0.5 \mathrm{mMol}, 116.15 \mathrm{mg})$ of camphorsulfonic acid (Bronsted acid) were added and dissolved in $2 \mathrm{ml}$ of dichloroethane under stirring. Then, 2.4 eq. $(1.2 \mathrm{mMol}, 84,10 \mathrm{mg}, 100 \mu \mathrm{l})$ of the methyl vinyl ketone (MVK) were added. The reaction was performed under reflux in a $10 \mathrm{~mL}$ Pirex ${ }^{\circledR}$ brand sealed tube at inert atmosphere (N2) overnight. The reaction was monitored by thin layer chromatography (TLC). The solvent was evaporated under reduced pressure, and then dissolved in $20 \mathrm{~mL}$ of aqueous saturated sodium bicarbonate solution. The solution was extracted with diethyl ether $(3 \times 10 \mathrm{ml})$. The organic phase was dried over anhydrous sodium sulfate, filtered, and concentrated under reduced pressure. The quinoline was purified by column chromatography using petroleum ether and ethyl ether eluents in an increasing polarity 10:0 $\rightarrow$ 9:1. Compound 1 was obtained as a brown solid in $42 \%$ yield. ${ }^{1} \mathrm{H}$ NMR $(300 \mathrm{MHz}$, $\left.\mathrm{CDCl}_{3}\right) \delta$ ppm: $\mathrm{H} 2(8.78 ; \mathrm{d}, \mathrm{J}=3.0 \mathrm{~Hz}, 1 \mathrm{H}), \mathrm{H} 5(8.15 ; \mathrm{d}, \mathrm{J}=$ $2.2 \mathrm{~Hz}, 1 \mathrm{H}), \mathrm{H} 8(7.97 ; \mathrm{d}, \mathrm{J}=9.0 \mathrm{~Hz}, 1 \mathrm{H}), \mathrm{H} 7(7.77$; dd, J = 9.0 and $2.2 \mathrm{~Hz}, 1 \mathrm{H}), \mathrm{H} 3(7.25 ; \mathrm{d}, \mathrm{J}=3.0 \mathrm{~Hz}, 2 \mathrm{H})$, and $\mathrm{CH}_{3}(2.68$; $\mathrm{s}, 3 \mathrm{H})$ as described previously by Ranu et al. [39].

\section{Synthesis of compounds 2, 3, 4, and 5}

A solution of $2 \mathrm{ml}$ of distilled dimethylformamide (DMF) and 1 eq. $(0.5 \mathrm{mMol}, 181.15 \mathrm{mg})$ of tert-butyl (2-iodophenyl) carbamate were added to a $10-\mathrm{mL}$ Pirex ${ }^{\circledR}$ brand sealed tube under stirring at inert atmosphere (N2). Following 6 eq. (3 $\mathrm{mMol}, 246.09 \mathrm{mg}$ ) of the anhydrous sodium acetate (base), 
1 eq. ( $0.5 \mathrm{mMol}, 112.25 \mathrm{mg}$ ) of the Palladium (II) acetate and 2 eq. ( $1 \mathrm{mMol}, 262.29 \mathrm{mg}$ ) of the triphenylphosphine were added. Then, 2.4 eq. (1.2 mMol) of the $\alpha, \beta$-unsaturated ketone of interest were added (MVK for compound 2, $(E)-3$ hexen-2-one for 3, $(E)$-6-fenilhex-3-en-2-one for 4, and $(E)$ 4-phenylbut-3-en-2-one for 5). The reaction was carried out overnight and monitored by thin layer chromatography (TLC) to observe the consumption of the reaction limiting reagent (aniline). Then, the solvent was evaporated under reduced pressure, and the crude reaction dissolved with $20 \mathrm{ml}$ of saturated sodium bicarbonate solution. The crude reaction was extracted with diethyl ether $(3 \times 10 \mathrm{ml})$. The organic phase was dried over anhydrous sodium sulfate, filtered, and concentrated under reduced pressure. The crude reaction was transferred to a reaction flask and dissolved in $5 \mathrm{ml}$ of distilled dichloromethane. Then, 10 eq. ( $5 \mathrm{mMol}, 816.95 \mathrm{mg}$ ) of trichloroacetic acid were added at stirring for $4 \mathrm{~h}$ at room temperature. The solvent was evaporated under reduced pressure, and the residue was diluted in $20 \mathrm{ml}$ of saturated sodium bicarbonate solution and extracted with diethyl ether $(3 \times 10$ $\mathrm{ml})$. The organic phase was dried over anhydrous sodium sulfate, filtered, and concentrated under reduced pressure. The product was purified by preparative plates with petroleum ether:ethyl ether in the ratio (9:1).

Compound 2-methylquinoline (2) was obtained as a brown solid in $70 \%$ yield. ${ }^{1} \mathrm{H}$ NMR $\left(300 \mathrm{MHz}, \mathrm{CDCl}_{3}\right) \delta$ ppm: $\mathrm{H} 4$ and $\mathrm{H} 5$ (8.02; t, J = 8.0 Hz, 2H), H8 (7.76; d, J = 8.5 Hz, 1H), $\mathrm{H} 7$ (7.66; ddd, $\mathrm{J}=8.5 ; 7.0$ and $1.4 \mathrm{~Hz}, 1 \mathrm{H}), \mathrm{H} 6$ (7. - 7.42; m, $1 \mathrm{H}), \mathrm{H} 3(7.29 ; \mathrm{d}, \mathrm{J}=8.1 \mathrm{~Hz}, 1 \mathrm{H})$ and $\mathrm{CH}_{3}(2.75 ; \mathrm{s}, 3 \mathrm{H}) .{ }^{13} \mathrm{C}$ NMR (300 MHz, CDCl3) $\delta$ ppm: $\mathrm{CH}_{3}$ (25.4), C10 (126.5), C9 (147.9), C2 (158.9).<smiles>Cc1ccc2ccccc2n1</smiles>

Compound 2-methyl-4-ethylquinoline (3) was obtained as a brown solid in $77 \%$ yield. $1 \mathrm{H} \mathrm{NMR}(300 \mathrm{MHz}, \mathrm{CDCl} 3) \delta$ ppm: H5 (7.99; dd, J = 7.6 and $1.8 \mathrm{~Hz}, 1 \mathrm{H}), \mathrm{H} 8$ (7.85; dd, $\mathrm{J}=$ 7.7 and $1.9 \mathrm{~Hz}, 1 \mathrm{H}), \mathrm{H} 6$ and $\mathrm{H} 7(7.54-7.45 ; \mathrm{m}, 2 \mathrm{H}), \mathrm{CH}_{2}$ (3.05; q, 2H), $\mathrm{CH}_{3}(2.66 ; \mathrm{s}, 3 \mathrm{H})$, and $\mathrm{CH}_{3}{ }^{\prime}(1.27 ; \mathrm{s}, 3 \mathrm{H}) .{ }^{13} \mathrm{C}$ NMR (300 MHz, $\left.\mathrm{CDCl}_{3}\right) \delta$ ppm: $\mathrm{C} 13\left(\mathrm{CH}_{3}-13.6\right), \mathrm{C} 12$ $\left(\mathrm{CH}_{2}-18.2\right), \mathrm{C} 11\left(\mathrm{CH}_{3}-20.4\right), \mathrm{C} 9$ (142.6), $\mathrm{C} 4$ (145.6), and C2 (150.8).<smiles>CCc1cc(C)nc2ccccc12</smiles>

Compound 2-methyl-4-phenethylquinoline (4) was obtained as a brown solid in $37 \%$ yield. ${ }^{1} \mathrm{H}$ NMR $\left(300 \mathrm{MHz}, \mathrm{CDCl}_{3}\right)$ $\delta$ ppm: H5 (8.06; dd, J = 8.4 and $0.6 \mathrm{~Hz}, 1 \mathrm{H}), \mathrm{H} 8$ (8.00; dd, $\mathrm{J}=8.4$ and $1.0 \mathrm{~Hz}, 1 \mathrm{H}), \mathrm{H} 7(7.70$; ddd, $\mathrm{J}=8.4 \mathrm{~Hz} ; 7.00$ and $1.4 \mathrm{~Hz}, 1 \mathrm{H})$, H6 (7.48; ddd, $\mathrm{J}=8.2 ; 7.00$ and $1.4 \mathrm{~Hz}, 1 \mathrm{H})$, phenyl (7.35-7.20; m, 5H), H3 (7.80: s, 1H), H1' (3.33; dd, $\mathrm{J}=9.6$ and $6.6 \mathrm{~Hz}, 2 \mathrm{H}), \mathrm{H} 2^{\prime}(3.05$; dd, $\mathrm{J}=9.6$ and $6.6 \mathrm{~Hz}, 2 \mathrm{H})$, and $\mathrm{CH}_{3}(2.69 ; \mathrm{s}, 3 \mathrm{H}) .{ }^{13} \mathrm{C}$ NMR $\left(300 \mathrm{MHz}, \mathrm{CDCl}_{3}\right) \delta \mathrm{ppm}$ : $\mathrm{C} 11$ ( $\left.\mathrm{CH}_{3}-25.2\right), \mathrm{C} 1^{\prime}\left(\mathrm{CH}_{2}-34.1\right), \mathrm{C} 2^{\prime}\left(\mathrm{CH}_{2}-36.2\right), \mathrm{C}^{\prime \prime}$ (141.1), C9 (147.9), C4 (147.4), and C2 (158.7).<smiles>Cc1cc(CCc2ccccc2)c2ccccc2n1</smiles>

Compound 2-methyl-4-phenylquinoline (5) was obtained as a brown solid in $17 \%$ yield. ${ }^{1} \mathrm{H} \mathrm{NMR}\left(300 \mathrm{MHz}, \mathrm{CDCl}_{3}\right) \delta$ ppm: H5 (8.08; d, J=8.4 Hz; 1H), H8 (7.85; dd, J=8.4 e $0.9 \mathrm{~Hz}, 1 \mathrm{H}), \mathrm{H} 7$ (7.66; ddd, $\mathrm{J}=8.4 ; 7.00$ and $1.4 \mathrm{~Hz} 1 \mathrm{H})$, phenyl and $\mathrm{H6}(7.56-7.39 ; \mathrm{m}, 6 \mathrm{H})$, and $\mathrm{H} 3$ (7.24: s, $1 \mathrm{H})$, $\mathrm{CH}_{3}$ (2.78; s, 3H). ${ }^{13} \mathrm{C}$ NMR $\left(300 \mathrm{MHz}, \mathrm{CDCl}_{3}\right) \delta \mathrm{ppm}$ : $\mathrm{C} 11\left(\mathrm{CH}_{3}-25.3\right), \mathrm{C} 9$ (138.1), C12 (148.4) C4 (148.5), and C2 (158.5).<smiles>Cc1cc(-c2ccccc2)c2ccccc2n1</smiles>

\section{In silico ADME prediction}

The physicochemical parameters for the quinoline derivatives were calculated using the online tool SwissADME. In this platform, it is possible to have free access to a set of fast and robust predictive models for physico-chemical, pharmacokinetic, and pharmacological properties of synthesized compounds [40, 41], since the calculation of in silico ADME parameters through digital tools is a strategy used to accelerate the development process of new drugs. The percentage of oral absorption (\% ABS) was calculated according to Zaheer et al. [42] through of equation: 
$\% \mathrm{ABS}=109-(0.345 \times$ PSA $)$

\section{Fungal strains}

Seventeen Candida strains: Candida albicans (ATCC 18804, CA 01, CA 05, CA 17), C. glabrata (CG RL24m, CG RL34 and CG RL49), C. krusei (CK 02, CK 03 and CK Den43), C. parapsilosis (CP RL13m, CP RL38 and CP RL52), and C. tropicalis (CT 07, CT 72A, CT 72P and ATCC 750) and thirteen dermatophytes strains Microsporum canis (MCA 01, MCA 29 and MCA 40), M. gypseum (MGY 42, MGY 50 and MGY 58), Trichophyton mentagrophytes (TME 16, TME 32, TME 40 and TME 60), and T. rubrum (TRU 45, TRU 47 and TRU 51). The CA 01, CG RL24m, CP RL13m, CT 72A, TME 16, TME 60, and TRU 45 are strains resistant to at least one class of antifungals. Candida strains were analyzed phenotypically by Vitek Yeast Biochemical Card (BioMerieux Vitek-Hazelwood, Missouri, USA). All strains are from the mycology collection of yeasts of the Federal University of Rio Grande do Sul (Porto Alegre, Brazil). The standard strains (ATCC 18804 and ATCC 750) were obtained from ATCC (American Type Culture Collection, Manassas, VA, USA) and used as control.

\section{Antifungal susceptibility testing}

Compounds $1-5$ were tested against all strains described previously. Thus, the compounds were submitted to the broth microdilution assay to determine their minimum inhibitory concentration (MIC). Each compound was tested at $100 \mu \mathrm{g} \mathrm{ml}^{-1}$, with concentrations ranging from 0.09 to $50 \mu \mathrm{g} \mathrm{ml}^{-1}$ in the assay. Thus, for dermatophytic species and Candida spp., the assay was performed according to protocol M38-A2 [43] and M27-A3 [44], respectively. Fluconazole (FLC) solution at $64 \mu \mathrm{g} \mathrm{ml}^{-1}$ was used as a drug control for the test.

\section{Cytotoxicity assay}

Green monkey kidney (Vero®) cells were used for cytotoxicity assay. Vero® cells were added in flasks and cultivated in DMEM High broth (Sigma-Aldrich, St. Louis, Missouri, EUA), supplemented with $20 \%$ heat-inactivated fetal bovine serum (FBS - Cripton, Andradina, São Paulo, Brasil), $1 \%$ penicillin and streptomycin both at $100 \mu \mathrm{g} / \mathrm{mL}$ (SigmaAldrich, St. Louis, Missouri, EUA) in $5 \% \mathrm{CO}_{2}$ atmosphere, and incubated at $37{ }^{\circ} \mathrm{C}$. When a confluence of $80-90 \%$ of the cell monolayer was obtained, the cells were detached to be subjected to the assay. Vero ${ }^{\circledR}$ cells at approximately $7 \times 10^{3}$ cells/well were dispensed into a 96-well microtiter and incubated for $24 \mathrm{~h}$ to obtain the cellular monolayer. Then, the cells were treated with compounds 3 and 5 at concentrations ranging from 6.25 to $100 \mu \mathrm{g} \mathrm{ml}{ }^{-1}$ during $48 \mathrm{~h}$ at $37{ }^{\circ} \mathrm{C}$ in $5 \% \mathrm{CO}_{2}$ atmosphere. As control without treatment, $0.5 \%$ DMSO was used. Then, a solution of MTT $0.5 \mu \mathrm{g} \mathrm{ml}^{-1}$ was added to the cells and the microplates incubated for $2 \mathrm{~h}$ at $37^{\circ} \mathrm{C}$. The staining presented by the cells is directly proportional to the number of viable cells and is measured by optical density. The microplates were read in a spectrophotometer (Spectramax 190-Molecular Devices) at $570 \mathrm{~nm}$. The assay was performed in triplicate according to Ishida et al. [45], with modifications.

\section{Hen's egg test on the chorioallantoic membrane (HET-CAM)}

HET-CAM assay has been accepted as an alternative model for in vivo tests because of the high sensitivity of the chorioallantoic membrane to show damages in the presence of irritant compounds. For this study, fresh fertile white Lohmann eggs (Lohmann selected Leghorn, LSL) were selected and maintained under controlled conditions. On the 10th day, the egg shell was removed carefully with a rotary tool (Dremel, WI). Then, $300 \mu \mathrm{l}$ of compound 5 at $500 \mu \mathrm{g} \mathrm{ml}^{-1}$, positive control $0.1 \mathrm{~mol}^{-1} \mathrm{NaOH}$ solution, and negative control $0.9 \%$ $\mathrm{NaCl}$ solution were added into each egg. The evaluation of effects caused by the compound was observed in $0.5,2$, and 5 min, after its application. The irritation score (IS) was expressed on the following scale: non-irritating or practically non-irritating $(0-4.9)$; moderate irritation (5-8.9), and severe or extreme irritation (9-21) [46], according to the equation:

$$
\begin{aligned}
I S= & \left(\left(\frac{(301-\text { Hemorrhage Time })}{300}\right) \times 5\right) \\
& +\left(\left(\frac{(301-\text { Lysis Time })}{300}\right) \times 7\right) \\
+ & \left(\left(\frac{(301-\text { Coagulation Time })}{300}\right) \times 9\right)
\end{aligned}
$$

\section{Histopathological evaluation in ex vivo model}

The possible dermal toxicity induced by compound 5 was evaluated on pig ear skin samples. Tissue samples from adult male pigs freshly slaughtered by São Clemente (Concordia, SC, Brazil) and supplied to Institute Federal of Santa Catarina (Concordia, SC, Brazil) were used. Pigs were slaughtered according to all rules of the Brazilian Ministry of Agriculture, respecting animal welfare [47]. Initially, pig ear skin samples were mounted in Franz diffusion cells (Logan Instrument Corp., NJ) with an area of $1.75 \mathrm{~cm}^{2}$. The epidermal side of the skin was exposed to phosphate-buffered saline (PBS) pH 7.0 (negative control) and $0.1 \mathrm{~mol} \mathrm{l}^{-1} \mathrm{NaOH}$ solution (positive control), for $6 \mathrm{~h}$ each. Under the same conditions, compound 5 was dissolved in PBS buffer at concentrations $25,100,200$, and $400 \mu \mathrm{g} \mathrm{ml}^{-1}$ and added on the skin samples. 
Then the treatment and the tissue fragments were collected, fixed in $10 \%$ formalin solution with neutral buffer, and stained with hematoxylin and eosin (HE). Finally, the tissues were examined under light microscopy. The experiments were carried out in triplicate.

\section{Micronucleus test}

The toxicological study of DNA damage at the chromosomal level is essential to identify the occurrence of chromosomal mutations, an important event in carcinogenesis [48]. Thus, venous blood was collected from an adult volunteer having over 18 years of non-use of medication by venipuncture. Lymphocytes were obtained by centrifugation gradient and immediately transferred to RPMI 1640 medium (protocol approved by the Ethics Committee of the Federal University of Pampa, under number 27045614.0.0000.5323). Then, cell culture flasks containing compound 5 at $100 \mu \mathrm{g} \mathrm{ml}{ }^{-1}$ were incubated at $37{ }^{\circ} \mathrm{C}$ during $72 \mathrm{~h}$ along with positive control (bleomycin at $3 \mu \mathrm{g} \mathrm{ml}^{-1}$ ) and negative control (PBS buffer at $\mathrm{pH}$ 7.4). Then, the slides containing the treatments were stained with Renylab $®$ and analyzed under optical microscope at $\times 1000$ magnification. Five hundred cells were counted in each slide and classified for the amount: mononuclear cells with the presence of micronucleus, binuclear cells with micronucleus, cells in necrotic process, and cells in the apoptotic process. The methodology followed Fenech [48] and Schmid [49], with modifications.

\section{Acute toxicity test in mealworms}

For this study, Tenebrio monitor larvae (Coleoptera: Tenebrionidae) were supplied by Predadora live food (Porto Alegre, RS, Brazil). The mealworms with a weight between 100 and $200 \mathrm{mg}$ and uniform color, without dark spots or grayish marks, were selected and anesthetized by cooling $\left(2{ }^{\circ} \mathrm{C}\right)$ for 2 minutes. Then, $50 \mu$ of compound 5 at $100 \mu \mathrm{g} \mathrm{ml}^{-1}$ was applied in each larva with support of a microsyringe into the hemocoel, at the second or third visible sternite above the legs, in the ventral portion. The larvae were incubated at $37{ }^{\circ} \mathrm{C}$ in Petri dishes containing a rearing diet. The number of dead larvae was recorded at $4 \mathrm{~h}$ intervals during $48 \mathrm{~h}$. The assay was performed in triplicate with groups of seven larvae, with a total of twenty-one larvae per each treatment. The methodology followed De Souza et al. [50], with modifications.

\section{Statistical analysis}

All statistical analyses were performed with GraphPad Prism 7.0 (GraphPad Software). The data were analyzed statistically through one-way ANOVA followed by Tukey's test with $p<0.05$ value considered significant. The experiment was performed three times in triplicate.

\section{Results and discussion}

Quinoline compounds were obtained from substituted anilines using the adapted methodologies of Skraup and Doebner-von Miller (compound 1), in addition to an innovative methodology that utilized the Heck-Mizoroki reactions (compounds 25) (Scheme 1). How is it possible to observe from the methodology based on Skraup and Doebner-von Miller, the reaction was carried out by reacting the aniline with the $\alpha, \beta$-unsaturated ketone, using as the catalyst the bronsted acid to give compound $142 \%$ yield. In the synthesis based on HeckMizoroki, a synthetic innovation was introduced by the protection of 2-iodoaniline with tert-butyl carbamate (BOC), an essential detail in the formation of quinolones. In the first step, the protected aniline was reacted with the $\alpha, \beta$-unsaturated ketone in basic conditions and under Palladium catalysis. Then, from the crude reaction, deprotection was performed with the addition of trifluoroacetic acid resulting in yields ranging from great to low $(2,70 \% ; 3,77 \% ; 4,37 \%$; and 5 , $17 \%)$. The variation in yields can be explained mainly by the steric and electronic nature of the different $\alpha, \beta$-unsaturated ketones. The compounds were purified by thin layer chromatography and/or by column chromatography. The structures of the synthesized compounds were confirmed by ${ }^{1} \mathrm{H} \mathrm{NMR},{ }^{13} \mathrm{C}$ NMR, and mass spectral like published previously and shown in supporting information.

The synthetic versatility presented by the quinoline nucleus facilitates the development of several structurally different derivatives, providing a broad spectrum of biological action [51]. In this study, positions C-2, C-4, and C-6 of the quinoline nucleus were modified to obtain antifungal active compounds. The quinoline derivatives presented selective antifungal action on the strains tested. Compounds 2 and 3 (MIC ranges $25-50 \mu \mathrm{g} / \mathrm{mL}$ ) were active only on yeast, whereas compound 5 (MIC ranges 12.5-25 $\mathrm{gg} \mathrm{ml}^{-1}$ ) demonstrated efficacy only on filamentous fungi. This anti-dermatophytic action was more effective, since the compound 5 (geometric means $\left.(\mathrm{GM})=19.14 \mu \mathrm{g} \mathrm{ml}^{-1}\right)$ demonstrated smaller GM values, when compared with the anti-Candida action presented by compounds $2\left(\mathrm{GM}=50 \mu \mathrm{g} \mathrm{ml}^{-1}\right)$ and $3(\mathrm{GM}=$ $47.19 \mu \mathrm{g} \mathrm{ml}^{-1}$ ). In addition to showing the lowest MIC values, compound 5 was active against all dermatophytic strains. On the other hand, compound 4 was active only against a yeast strain, while compound 1 showed no activity on any evaluated fungal species (Table 1).

The compound 5 has a phenyl substituent at C-4 position of the quinoline ring, suggesting that the presence of this group, directly attached to the nucleus, is fundamental to antidermatophytic action when we compare the tested molecules 
with each other. According to Patel et al. [52], the introduction of a phenyl substituent into the quinoline ring resulted in a good microbiological action. It is possible to suggest that the introduction of a methyl substituent at $\mathrm{C}-2$ position and a phenyl group at $\mathrm{C}-4$ position of the quinoline ring (compound 5 ) resulted in higher efficiency when compared with other compounds. The higher efficiency presented by compound 5 may occur due to the inductive effect of the methyl group, facilitating the electronic effects and occurrence of interactions with the biological targets. For El Shehry et al. [38] and Singh et al. [30], the introduction of a methyl group into quinoline derivatives showed a good action against Aspergillus and Mycobacterium genus, respectively. However, only the presence of methyl was not enough for developing action on dermatophytes, since the compounds 1-4 did not present activity on these genera. On the other hand, compounds 2 and 3 present selective anti-candida action. These compounds also have a methyl substituent at C-2 position of the quinoline ring. A C-2 methyl and C-4 ethyl disubstitution in the derivative 3 promoted enhances in the yeast activity when compared with a monosubstitution at $\mathrm{C}$ 2 position of the quinoline core (2). According to Liberato et al. [37], derivatives with C-2,4 disubstituents in the quinoline ring presented anti-Candida and anti-Cryptococcus action. The selective anti-Candida action may be due to compounds 2 and 3 have lower molecular weight and lower electrons conjugation when compared with the other compounds. This lower molecular structure could facilitate the penetration of these compounds through yeast cells.

The compounds 1 and 4 were not effective against any genus evaluated. The absence of a substituent at C-2 position along with bromine an electron-withdrawing group at C-6 position of quinoline nucleus could have contributed to the loss of antifungal action by compound 1 . Moreover, the ethylphenyl, a flexible electron-rich substituent at C-4 position, has led to the loss of activity by compound 4 . This can suggest that the presence of a phenyl group directly linked to the quinoline nucleus can give rigidity necessary for antifungal activity. Finally, we can suggest that the antifungal selectivity presented by quinoline derivatives can be due to its structural alterations since modifications in the substituents attached to the ring interfered in the performance of the biological action of compounds. Thus, the presence of determinate substituents attached to the quinoline nucleus seems to be related for the presence of antifungal potential. However, the number of compounds evaluated is small to certify these structural relationships. The selective action of the compounds on yeasts or filamentous fungi may also be due to the
Scheme 1 General methodologies used for synthesis of the quinolines and their respective yields
Adapted methodology of Skraup and Doebner-von Miller<smiles>C=CC(C)=O</smiles>

Methodology based on the reactions of Heck-Mizoroki<smiles>[R2]C=CC([R])=O</smiles> 
Table 1 Minimum inhibitory concentration (MIC $\mu \mathrm{g} \mathrm{ml}^{-1}$ ) values refer to compounds $1-5$ against Candida spp. and dermatophytes strains

\begin{tabular}{|c|c|c|c|c|c|c|c|c|c|c|c|c|c|}
\hline Candida spp. & 1 & 2 & 3 & 4 & 5 & FLC & Dermatophytes & 1 & 2 & 3 & 4 & 5 & FLC \\
\hline ATCC 18804 & $>50$ & 50 & 50 & $>50$ & $>50$ & 2 & MCA 01 & $>50$ & $>50$ & $>50$ & $>50$ & 12.5 & $>64$ \\
\hline CA 01 & $>50$ & $>50$ & $>50$ & $>50$ & $>50$ & 8 & MCA 29 & $>50$ & $>50$ & $>50$ & $>50$ & 12.5 & $>64$ \\
\hline CA 05 & $>50$ & $>50$ & 50 & $>50$ & $>50$ & 16 & MCA 40 & $>50$ & $>50$ & $>50$ & $>50$ & 25 & $>64$ \\
\hline CA 17 & $>50$ & $>50$ & 50 & $>50$ & $>50$ & 8 & MGY 42 & $>50$ & $>50$ & $>50$ & $>50$ & 12.5 & $>64$ \\
\hline CG RL24 & $>50$ & $>50$ & 50 & $>50$ & $>50$ & 16 & MGY 50 & $>50$ & $>50$ & $>50$ & $>50$ & 12.5 & $>64$ \\
\hline CG RL34 & $>50$ & $>50$ & 50 & $>50$ & $>50$ & 64 & MGY 58 & $>50$ & $>50$ & $>50$ & $>50$ & 12.5 & $>64$ \\
\hline CG RL49 & $>50$ & $>50$ & $>50$ & $>50$ & $>50$ & 16 & TME 16 & $>50$ & $>50$ & $>50$ & $>50$ & 25 & $>64$ \\
\hline CK 02 & $>50$ & $>50$ & $>50$ & $>50$ & $>50$ & 8 & TME 32 & $>50$ & $>50$ & $>50$ & $>50$ & 12.5 & $>64$ \\
\hline CK 03 & $>50$ & $>50$ & 50 & $>50$ & $>50$ & 64 & TME 40 & $>50$ & $>50$ & $>50$ & $>50$ & 12.5 & $>64$ \\
\hline CK Den 43 & $>50$ & 50 & 25 & $>50$ & $>50$ & 64 & TME 60 & $>50$ & $>50$ & $>50$ & $>50$ & 25 & $>64$ \\
\hline CP RL13 & $>50$ & $>50$ & 50 & $>50$ & $>50$ & 32 & TRU 45 & $>50$ & $>50$ & $>50$ & $>50$ & 25 & $>64$ \\
\hline CP RL38 & $>50$ & $>50$ & $>50$ & $>50$ & $>50$ & 4 & TRU 47 & $>50$ & $>50$ & $>50$ & $>50$ & 25 & $>64$ \\
\hline CP RL52 & $>50$ & 50 & $>50$ & $>50$ & $>50$ & 32 & TRU 51 & $>50$ & $>50$ & $>50$ & $>50$ & 25 & $>64$ \\
\hline СТ 07 & $>50$ & 50 & 50 & $>50$ & $>50$ & 8 & - & $>50$ & $>50$ & $>50$ & $>50$ & - & - \\
\hline CT 72A & $>50$ & $>50$ & 50 & $>50$ & $>50$ & 128 & - & $>50$ & $>50$ & $>50$ & $>50$ & - & - \\
\hline CT 72P & $>50$ & 50 & 50 & $>50$ & $>50$ & 64 & - & $>50$ & $>50$ & $>50$ & $>50$ & - & - \\
\hline ATCC 750 & $>50$ & $>50$ & 50 & $>50$ & $>50$ & 4 & - & $>50$ & - & $>50$ & $>50$ & - & - \\
\hline Geometric mean & - & 50 & 47.19 & - & - & 17.35 & Geometric mean & - & - & - & - & 19.14 & - \\
\hline MIC range & - & $50->50$ & $50->50$ & - & - & $4-128$ & MIC range & - & - & - & - & $12.5-25$ & - \\
\hline
\end{tabular}

Microsporum canis (MCA 01, MCA 29, and MCA 40); Microsporum gypseum (MGY 42, MGY 50, and MGY 58); Trichophyton mentagrophytes (TME 16, TME 32, TME 40, and TME 60); Trichophyton rubrum (TRU 45, TRU 47, and TRU 51). Candida albicans (CA 01, CA 02, and CA 17); C. glabrata (CG RL24, CG RL 34, and CG RL49); C. krusei (CK 02, CK 03, and CK Den43); C. parapsilosis (CP RL13, CP RL38, and CP RL52); C. tropicalis (CT 07, CT 72A, CT 72P, and ATCC 750). Resistant strains at the highest concentration tested for each compound ( $\left.\mathrm{MIC}>50 \mu \mathrm{g} \mathrm{ml}{ }^{-1}\right)$ and fluconazole ( $\mathrm{MIC}>64 \mu \mathrm{g} \mathrm{ml}^{-1}$ ). FLC: fluconazole solution used as control of test

morphological characteristics displayed by these organisms, which may affect the penetration of the compound into fungal cells.

In silico ADME prediction of physical-chemical parameters for quinoline compounds was performed. As a result, all compounds showed satisfactory physicochemical parameters by online platform SwissADME. All compounds presented LogP compatible with a good oral bioavailability due to lipophilic character, highlight compound 4 with higher $\log \mathrm{P}$ (4.29). The prediction of $\log S$ indicated a good oral bioavailability for compounds 4 and 5 ( $\operatorname{LogS}>-4)$. Moreover, all compounds have a percentage of oral absorption (ABS) major to 100 and present acceptable values for probable skin permeation (Table 2). The evaluation of these parameters is fundamental to indicate the potential of a compound as a new drug.

Due to the higher antifungal efficacy, compounds 3 and 5 were selected for evaluation of cell viability on Vero cells. As a result, the compounds did not show cytotoxicity at concentrations related to their MIC values $\left(12.5-50 \mu \mathrm{g} \mathrm{ml}^{-1}\right)$. Even at the highest concentration evaluated $\left(100 \mu \mathrm{g} \mathrm{ml}^{-1}\right)$, a high percentage of viable cells can be observed in the presence of compounds tested. Thus, there were no significant difference between the groups evaluated when compared with the control $(p>0.05)$, indicating the absence of cytotoxicity (Fig. 1).
Similar to our findings, diverse studies have shown that quinoline derivatives with microbiological action present low cytotoxicity on Vero cells: $\mathrm{IC}_{50}>30 \mu \mathrm{g} \mathrm{ml}^{-1}$ [53], $\mathrm{IC}_{50}>200 \mu \mathrm{g} \mathrm{ml}^{-1}$ [54], and $\mathrm{IC}_{50}>50 \mu \mathrm{g} \mathrm{ml}^{-1}$ [55]. About the chemical structure, the viability of Vero cells does not seem to depend on the substituents introduced at the C-2.4 positions of the quinoline ring, since two compounds exhibited similar behavior on these cells. The discovery of the compounds with low toxicity is a challenge for antifungal clinical

Table 2 In silico ADME parameters calculated for quinoline derivatives (compounds 1-5)

\begin{tabular}{llllll}
\hline & 1 & 2 & 3 & 4 & 5 \\
\hline MW & 220.09 & 143.0 & 171.10 & 247.14 & 219.10 \\
LogP & 3.08 & 2.45 & 3.09 & 4.29 & 3.84 \\
LogS & -3.25 & -2.51 & -3.34 & -4.81 & -4.20 \\
$\%$ ABS & $>100$ & $>100$ & $>100$ & $>100$ & $>100$ \\
LogKp & -5.31 & -5.33 & -4.94 & -4.39 & -4.64 \\
\hline
\end{tabular}

$M W$, molecular weight $<500 \mathrm{~g} \mathrm{~mol}^{-1} ; \log P$, partition coefficient $(<5.0)$; $\log S$, solubility coefficient (>-4); \%ABS, percentage of oral absorption (> 100); $\log K p$, logarithm of cutaneous permeability; $A D M E$, absorption, distribution, metabolism, excretion. The pharmacokinetic parameters were calculated through online platform SwissADME 

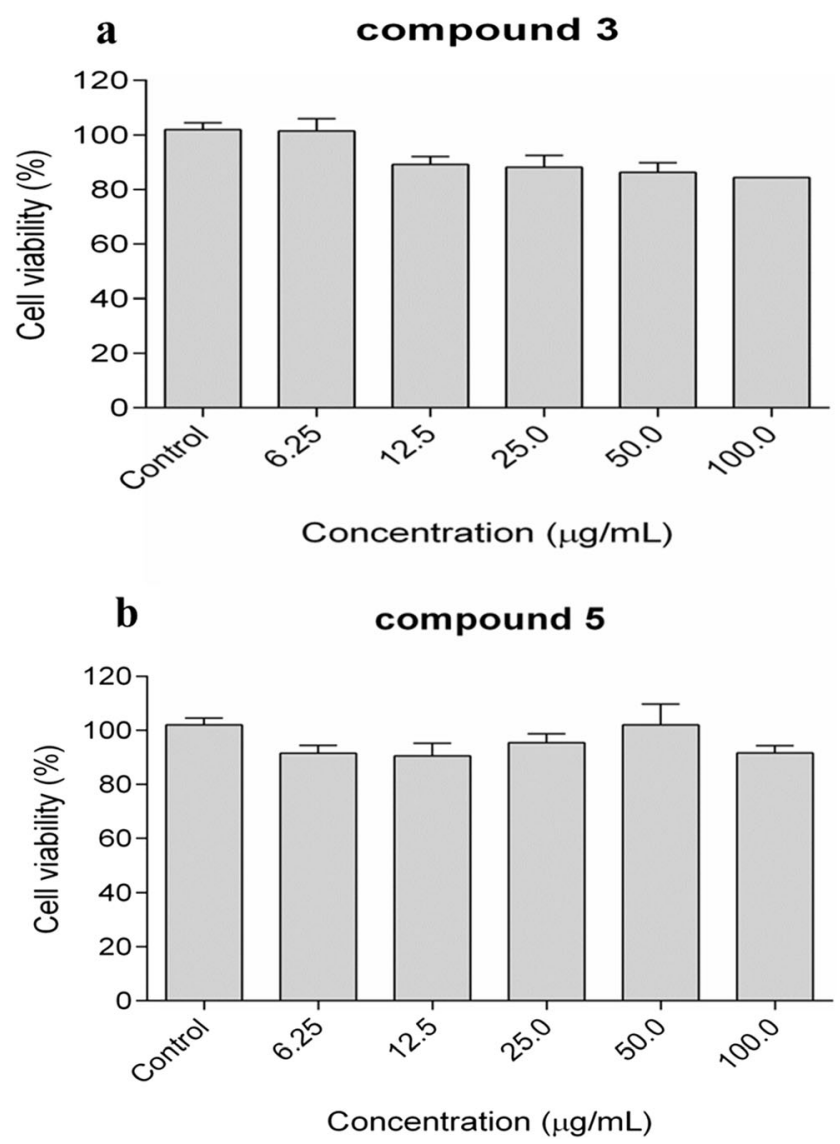

Fig. 1 Dose-response relationship on the viability of Vero® cells after $48 \mathrm{~h}$ of exposition of compounds 3 (a) and 5 (b) at $6.25,12.5,25,50$, and $100 \mu \mathrm{g} \mathrm{ml}^{-1}$. As a cytotoxicity control, $0.5 \%$ DMSO was used. Data are expressed as mean \pm standard error of three independent experiments

therapy. Most oral antifungal drugs currently used in the medical clinic cause some kind of toxic damage in the patient, such as nephrotoxicity and hepatotoxicy, the main toxic effects related to the literature due to drug [18, 20, 21, 56-59]. However, our results suggest that quinoline derivatives are safe for use in mammalian cells, although in vivo cytotoxicity assays are still required. Because of the greater antifungal efficacy and low cytotoxicity, compound 5 was chosen to proceed with the other toxicity tests in this study.

Like the PBS control, compound 5 was not able to cause chromosomal level DNA damage at concentrations $\leq$ $100 \mu \mathrm{g} \mathrm{ml}^{-1}$, since both did not induce micronucleus events. Thus, there was no significant difference between compound 5 and PBS control $(p>0.05)$. However, compound 5 showed a significant difference when compared with bleomycin control $(p<0.05)$ (Fig. 2).

These data demonstrate the absence of genotoxic potential by compound 5 even at concentrations greater than its MIC's values, suggesting safety for its use in mammalian cells. The importance of developing novel antifungal agents that do not induce genotoxicity is crucial to ensure safety to the patient. According to Uno et al. [60], quinoline derivatives does not

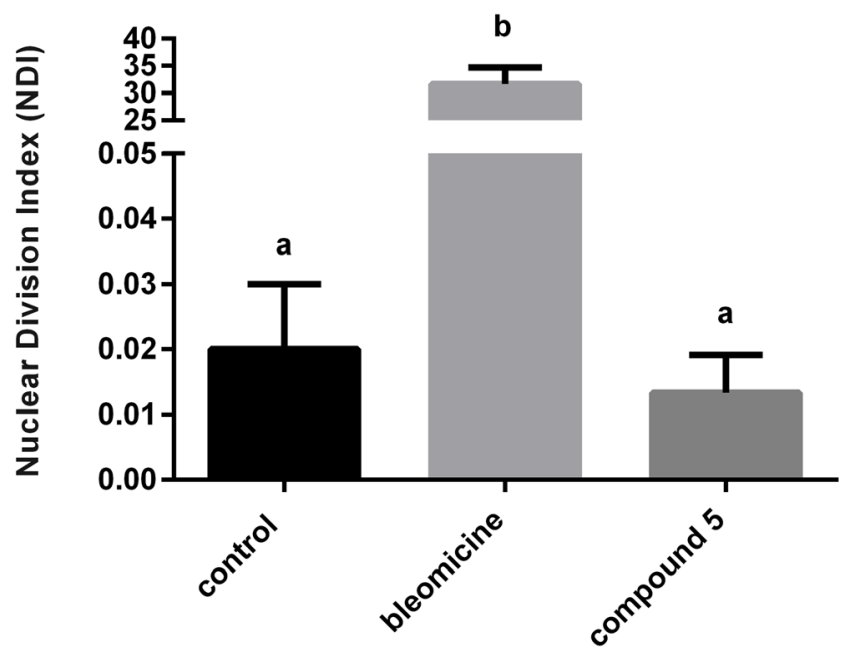

Fig. 2 The mean frequency of micronucleus in binuclear cells expressed as nuclear division index (NDI) after treatment with compound 5 $\left(100 \mu \mathrm{g} \mathrm{ml}^{-1}\right)$, positive control $\left(\mathrm{PC}=\right.$ bleomycin $\left.3 \mu \mathrm{g} \mathrm{ml}^{-1}\right)$, and negative control $(\mathrm{NC}=$ phosphate buffer solution-PBS). Data expressed as mean \pm standard deviation performed at each test triplicate $(n=3)$. The different letters in each group represent a statistically significant difference $(p<0.05)$

induce the formation of micronucleus events in the bone marrow and gastrointestinal tract cells of rats. Similarly, for Suzuki et al. [61], structural modifications in a quinoline derivative were unable to induce the formation of micronucleated lung fibroblast cells in the hamster. In opposition to these findings, antifungals used against candidiasis and dermatophytosis can induce severe mutagenicity in the cells of the patient. According to Yuzbasioglu et al. [62], fluconazole at 25 and $50 \mu \mathrm{g} \mathrm{ml}^{-1}$ increased the micronucleus frequency in human leukocyte cultures. Similarly, griseofulvin, a strong aneuploidy-inducing agent, also promoted the micronucleus events formation in these same cells [63]. Our results are promising, since quinoline derivatives have a good safety profile when compared to the current antifungals.

At $24 \mathrm{~h}$ after administration of compound 5 and PBS control, T. molitor larvae survival rate remained at $95 \%$ on both treatments. At $48 \mathrm{~h}$, the compound also presented similar behavior on the survival rate of larvae (survival rate of approximately 75\%) when compared with PBS control. Moreover, compound 5 was able to maintain a high mealworms survival rate even at concentrations higher than their MIC's values (Fig. 3). Invertebrate hosts, such as T. molitor, have been used as a new alternative model for the evaluation of in vivo systemic toxicity of different compounds, avoiding the use of vertebrates in toxicity preliminary tests $[50,64]$. Our results reinforce the choice of $T$. molitor as a great alternative model for the evaluation of in vivo systemic toxicity. Through the prediction of physical-chemical parameters, compound 5 proved to be lipophilic and presented good coefficients of solubility, leading to a percentage of oral absorption desirable. These results suggest that this compound probably presented a 


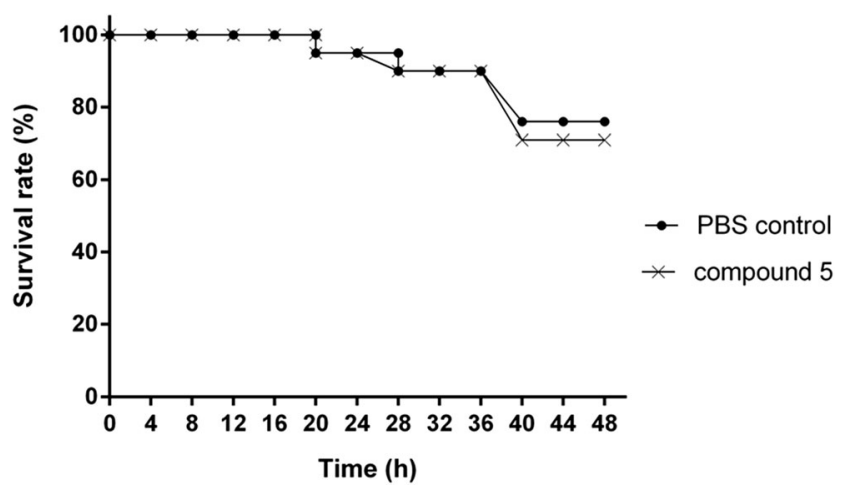

Fig. 3 Kaplan-Meier plots showing survival curve of mealworm's submitted to compound 5 at $100 \mu \mathrm{g} \mathrm{m}^{-1}(\times)$ and phosphate buffer solution (PBS) $(\bullet)$

good oral bioavailability in T. molitor. This is the first study evaluating the potential of a quinoline derivative to cause systemic toxicity in this organism. However, studies in mammalian animal models are needed to confirm our results.

Assessments of toxicological parameters at the topical level were also performed in compound 5. The antifungal potential coupled with the absence of cytotoxicity and genotoxicity demonstrated by compound 5 led to evaluation of its toxicity in ex vivo alternative models. The compound did not induce irritability and allergenicity on the chorioallantoic membrane of the hen's eggs (IS = 2.47). Thus, the compound was classified as non-irritant. Due to its non-allergenic nature, compound 5 was subject to histopathological evaluation. The compound did not cause changes and histopathological damage on pig ear skin cells at any of concentrations related to their MIC's values (12.5-100 $\mu \mathrm{g} \mathrm{ml}^{-1}$ ), demonstrating possible security for its topical use (Fig. 4).

The HET-CAM assay is an important preliminary test for measuring the ability of a compound to induce toxicity to the mucous membranes. Thus, compound 5 did not induce irritability in the chorioallantoic membrane and did not provoke mucosal allergenicity. These previous results are essential and suggest that this compound is safe for topical use. In addition, compound 5 presented Log Kp acceptable for skin permeability, which reinforces its application as a possible antifungal topical therapy. Current antifungals used to treatment of superficial and cutaneous dermatophytosis have present topical toxicity severe. The topical use of terbinafine and ketoconazole cause allergy to the skin and histopathological alternations in the stratum corneum $[19,65]$. Moreover, the topical treatment of dermatophytic onychomycosis with ciclopirox olamine has resulted in nail disorder, pruritus, rash, and contact dermatitis [66]. In this context, compound 5 is a promising candidate for the development of new topic formulations against superficial and cutaneous dermatophytosis.

\section{Conclusion}

This study is unprecedented and highlights the advantages of knowledge about the pharmacological potential of quinoline derivatives. These compounds have demonstrated selective and potent anti-dermatophytic and anti-yeast action against species of difficult treatment. Compound 5 presents a safe toxicological profile at the topical and systemic level,

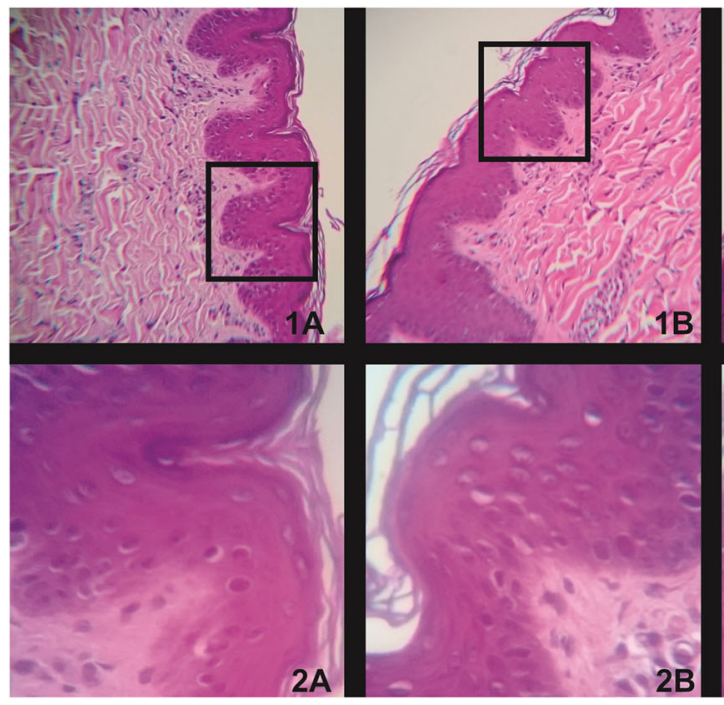

Fig. 4 Histopathological evaluation of swine epidermal cells treated with compound 5 and negative control (PSB) at 100 and 400 times magnification. $1 \mathrm{~A}$ and $2 \mathrm{~A}$ Swine epidermal cells treated with compound 5 $\left(25 \mu \mathrm{g} \mathrm{ml}^{-1}\right)$ at 100 and 400 times magnification, respectively. $1 \mathrm{~B}$ and 2B) Swine epidermal cells treated with compound $5\left(100 \mu \mathrm{g} \mathrm{ml}^{-1}\right)$ at 100 and 400 times magnification, respectively. $1 \mathrm{C}$ and $2 \mathrm{C}$ Swine epidermal

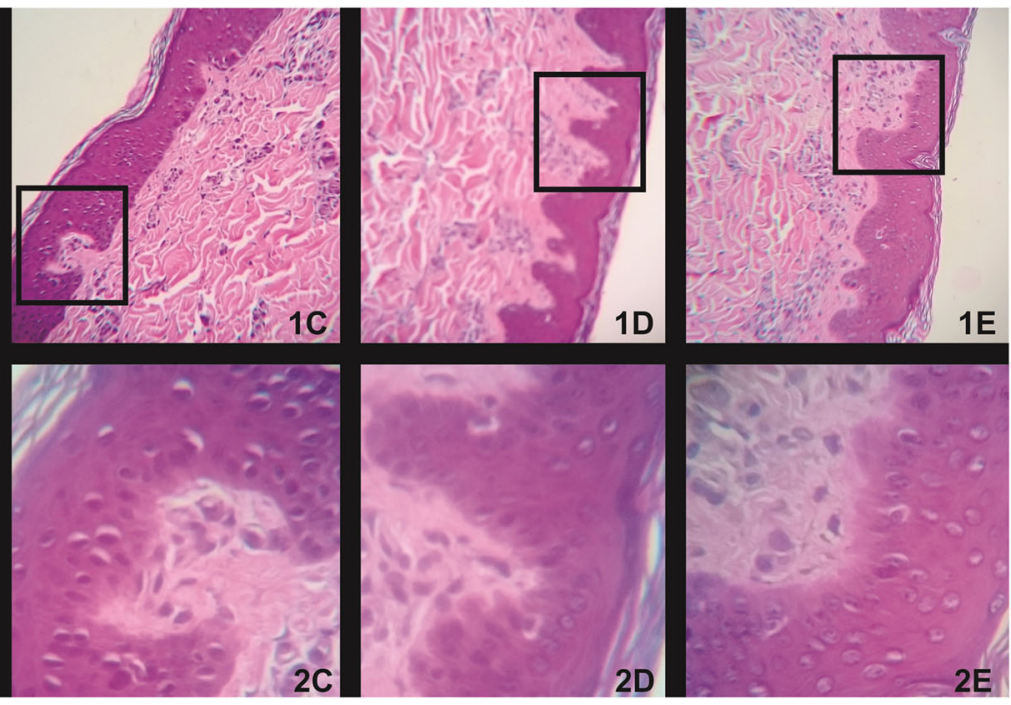

cells treated with compound $5\left(200 \mu \mathrm{g} \mathrm{ml}^{-1}\right)$ at 100 times and 400 times magnification. 1D and 2D Swine epidermal cells treated with compound $5\left(400 \mu \mathrm{g} \mathrm{ml}^{-1}\right)$ at 100 and 400 times magnification, respectively. 1E and 2E Swine epidermal cells treated with phosphate buffer solution (PBS) pH 7.0 at 100 and 400 times magnification, respectively 
suggesting its indication as a strong candidate for the development of a new effective compound against dermatophytosis. This study is the starting point for further researches involving the therapeutic applicability of this compound.

Acknowledgments Alexandre Meneghello Fuentefria is grateful to Conselho Nacional de Desenvolvimento Científico e Tecnológico (CNPq) for the PQ fellowships (Edital Universal 2018).

Funding information This study was supported by Coordenação de Aperfeiçoamento Pessoal de Nível Superior (CAPES) and Fundação de Amparo à Pesquisa do Estado do Rio Grande do Sul (FAPERGSEDITAL 04/2016-PRONUPEQ 2016).

\section{Compliance with ethical standards}

Conflict of interest The authors declare that they have no conflict of interest.

\section{References}

1. Achterman RR, White TC (2013) Dermatophytes. Curr Biol 23: $551-552$

2. Dalla Lana DF, Batista BG, Alves SH, Fuentefria AM (2016) Dermatophytosis: etiologic agents, clinical forms, therapy and new perspectives of treatment. Clin Biomed Res 36:230-241

3. Saxena P, Mamta RS, Hooda M (2017) A review on superficial fungal infections: clinical symptoms and treatment. World $\mathrm{J}$ Pharm Pharma Sci 6:646-658

4. Teklebirhan G, Bitew A (2015) Prevalence of dermatophytic infection and the spectrum of dermatophytes in patients attending a tertiary hospital in Addis Ababa. Ethiopia Int J Microbiol:1-6

5. Sahoo AK, Mahajan R (2016) Management of tinea corporis, tinea cruris, and tinea pedis: a comprehensive review. Indian Dermatol Online J 7:77-86

6. Song X, Wei W, Lai K, Zhen-Dan H, Hong-Jie Z (2018) In vivo antifungal activity of dipyrithione against Trichophyton rubrum on guinea pig dermatophytosis models. Biomed Pharmacother 108: 558-564

7. Rouzaud C, Lanternier F, Puel (2016) A primary immunodeficiencies and dermatophytosis. In: Carvalho A (ed) Immunogenetics of Fungal Diseases. Springer, pp 121-133

8. Ramos LDS, Barbedo LS, Braga-Silva LA, Dos Santos AL, Pinto MR, Sgarbi DB (2015) Protease and phospholipase activities of Candida spp. isolated from cutaneous candidiasis. Rev Iberoam Micol 32:122-125

9. Pappas PG, Kauffman CA, Andes DR, Clancy CJ, Marr KA, Ostrosky-Zeichner L, Reboli AC, Schuster MG, Vazquez JA, Walsh TJ, Zaoutis TE Sobel JD (2016) Clinical practice guideline for the management of candidiasis: 2016 update by the infectious diseases society of America. Clin Infect Dis 62:e1-e50

10. Pfaller MA, Castanheira M (2016) Nosocomial candidiasis: antifungal stewardship and the importance of rapid diagnosis. Med Mycol 54:1-22

11. Fuentefria AM, Andrade SF, Silveira GP, Kulkamp I, Pippi B, Machado MM, De Oliveira LFS, Cruz L, Frizzo C, Martins AF (2016) Caracterização do perfil de susceptibilidade a antifúngicos azólicos de uma micoteca como embasamento para estratégias de combate à candidemias. J Inf Control 5:1-11
12. Polvi EJ, Li XO, Meara TR, Leach MD, Cowen LE (2015) Opportunistic yeast pathogens: reservoirs, virulence mechanisms, and therapeutic strategies. Cell Mol Life Sci 72:2261-2287

13. Farmakiotis D, Kontoyiannis DP (2017) Epidemiology of antifungal resistance in human pathogenic yeasts: current viewpoint and practical recommendations for management. Int $\mathrm{J}$ Antimicrob Agents 50:318-324

14. Jensen RH (2016) Resistance in human pathogenic yeasts and filamentous fungi: prevalence, underlying molecular mechanisms and link to the use of antifungals in humans and the environment. Dan Med J 63:B5288

15. Perlin DS, Rautemaa-Richardson R, Alastruey-Izquierdo A (2017) The global problem of antifungal resistance: prevalence, mechanisms, and management. Lancet Infect Dis 17:e383-ee39

16. Wiederhold NP (2017) Antifungal resistance: current trends and future strategies to combat. Infect Drug Resist 10:249-259

17. Salehi Z, Shams-Ghahfarokhi M, Razzaghi-Abyaneh M (2018) Antifungal drug susceptibility profile of clinically important dermatophytes and determination of point mutations in terbinafineresistant isolates. Eur J Clin Microbiol Infect Dis 37:1841-1846

18. Okuyan H, Altin C (2013) Heart failure induced by itraconazole. Indian J Pharm 45:524-535

19. Liu J, Warshaw EM (2014) Allergic contact dermatitis from ketoconazole. Cutis. 9:112-114

20. Tverdek FP, Kofteridis D, Kontoyiannis DP (2016) Antifungal agents and liver toxicity: a complex interaction. Expert Rev AntiInfect Ther 14:765-777

21. Shibata Y, Hagihara M, Kato H, Kawasumi N, Hirai J, Nishiyama N, Asai N, Koizumi Y, Yamagishi Y, Matsuura K, Mikamo H (2017) Caspofungin versus micafungin in the incidence of hepatotoxicity in patients with normal to moderate liver failure. J Infect Chemother 23:349-353

22. Keri RS, Patil SA (2014) Quinoline: a promising antitubercular target. Biomed Pharmacother 68:1161-1175

23. El-Gamal KMA, Sherbiny FF, El-Morsi AM, Abu-El-khair HE, Eissa IH, El-Sebaei MM (2015) Design, synthesis and antimicrobial evaluation of some novel quinoline derivatives. Pharm Pharmacol Int J 2:00036

24. Pinheiro AC, Bispo MLF, Souza MVN (2010) Importance of quinoline nucleus and its derivatives in drug discovery. Rer Fitos 5:5363

25. Chung PY, Bian ZX, Pun HY, Dessy C, Chan AS, Chui CH, Tang JC, Lam KH (2015) Recent advances in research of natural and synthetic bioactive quinolines. Future Med Chem 7:947-967

26. Parhizgar R, Tahghigh A (2017) Introducing new antimalarial analogues of chloroquine and amodiaquine: a narrative review. Iran J Med Sci 42:115 Corpus ID: 17353632

27. Touret F, Lamballerie L (2020) Of chloroquine and COVID-19. Antivir Res 177:104762

28. Colson P, Rolain JM, Lagier JC, Brouqui P, Raoult D (2020) Chloroquine and hydroxychloroquine as available weapons to fight COVID-19. Int J Antimicrob Agents. https://doi.org/10.1016/j. ijantimicag.2020.105932

29. Afzal O, Kumar S, Haider MR, Ali MR, Kumar R, Jaggi M, Bawa S (2015) A review on anticancer potential of bioactive heterocycle quinoline. Eur J Med Chem 97:871-910

30. Singh S, Kaur G, Mangla V, Gupta MK (2015) Quinoline and quinolones: promising scaffolds for future antimycobacterial agents. J Enzyme Inhib Med Chem 30:492-504

31. Wen X, Wang S, Liu D, Gong G, Quan Z (2015) Synthesis and evaluation of the anti-inflammatory activity of quinoline derivatives. Med Chem Res 24:2591-2603

32. Casal JJ, Asís SE (2017) Natural and synthetic quinoline derivatives as antituberculosis agentes. Austin Tuberc Res Treat 2:1007 
33. Kadri D, Crater AK, Lee H, Solomon VR, Ananvoranich S (2013) The potential of quinoline derivatives for the treatment of Toxoplasma gondii infection. Exp Parasitol 35:135-144

34. Desai NC, Dodiya AM (2014) Synthesis, characterization and antimicrobial screening of quinoline based quinazolinone-4thiazolidinone heterocycles. Arab J Chem 7:906-913

35. Teng P, Li C, Peng Z, Vanderschouw AM, Nimmagadda A, Su M, Li Y, Sun X, Cai J (2018) Facilely accessible quinoline derivatives as potent antibacterial agents. Bioorg Med Chem 26:3573-3579

36. Kumar S, Bawa S, Drabu S, Gupta H, Machwal L, Kumar R (2011) Synthesis, antidepressant and antifungal evaluation of novel 2chloro-8-methylquinoline amine derivatives. Eur J Med Chem 46: 670-675

37. Liberato NA, Simões JB, Silva SP, Da Silva CJ, Modolo LV, De Fátima A, Fernandes AS (2017) Quinolines: microwave-assisted synthesis and their antifungal, anticancer and radical scavenger properties. Bioorg Med Chem 25:1153-1162

38. El Shehry MF, Ghorab MM, Abbas SY, Fayed EA, Shedid SA, Ammar YH (2018) Quinoline derivatives bearing pyrazole moiety: synthesis and biological evaluation as possible antibacterial and antifungal agents. Eur J Med Chem 143:1463-1473

39. Ranu BC, Hajra A, Dey SS, Jana U (2003) Efficient microwaveassisted synthesis of quinolines and dihydroquinolines under solvent-free conditions. Tetrahedron. 59:813-819

40. Zoete V, Daina A, Bovigny C, Michielin O (2016) SwissSimilarity: a web tool for low to ultra-high-throughput ligand-based virtual screening. J Chem Inf Model 58:399-1404

41. Daina A, Michielin O, Zoete V (2017) SwissADME: a free web tool to evaluate pharmacokinetics, druglikeness and medicinal chemistry friendliness of small molecules. J Chem Inf Model 7: 427-517

42. Zaheer Z, Khan FAK, Sangshetti JN, Patil RH (2015) Efficient onepot synthesis, molecular docking and in silico ADME prediction of bis-(4-hydroxycoumarin-3-yl) methane derivatives as antileishmanial agents. EXCLI J 14:935-947

43. Clinical and Laboratory Standards Institute (CLSI) (2008) Reference method for broth dilution antifungal susceptibility testing of filamentous fungi; Approved Standard, 2nd edn. CLSI Document M38-A2. Clinical Laboratory Standards Institute, Wayne

44. Clinical and Laboratory Standards Institute (CLSI) (2008) Reference method for broth dilution antifungal susceptibility testing of yeasts; Approved Standard, 3rd edn. CLSI Document M27A3. Clinical Laboratory Standards Institute, Wayne

45. Ishida K, Rodrigues JCF, Cammerer S, Urbina JA, Gilbert I, De Souza W, Rozental S (2011) Synthetic arylquinuclidine derivatives exhibit antifungal activity against Candida albicans, Candida tropicalis and Candida parapsilopsis. Ann Clin Microbiol Antimicrob 10:3

46. Interagency Coordinating Committee on the Validation of Alternative Methods (ICCVMA) (2010) The hen's egg testchorioallantoic membrane (HET-CAM) test method. National Toxicology Program, Research Triangle Park

47. Brasil (2013) Ministério da agricultura. Instrução Normativa $n^{\circ} 3 /$ 2000 de 17 de janeiro de 2000. Aprova regulamento técnico de métodos de insensibilização para abate humanitário de animais de açougue

48. Fenech M (2000) The in vitro micronucleus technique. Mutat Res 455:81-95

49. Schmid W (1975) The micronucleus test. Mutat Res 31:09-15

50. De Souza PC, Morey AT, Castanheira GM, Bocate KP, Panagio LA, Ito FA, Almeida RS (2015) Tenebrio molitor (Coleoptera:
Tenebrionidae) as an alternative host to study fungal infections. J Microbiol Methods 118:182-186

51. Solomon VR, Lee H (2011) Quinoline as a privileged scaffold in cancer drug discovery. Curr Med Chem 18:1488-1508

52. Patel SR, Gangwal R, Sangamwar AT, Jain R (2015) Synthesis, biological evaluation and 3D QSAR study of 2,4-disubstituted quinolines as anti-tuberculosis agents. Eur J Med Chem 93(93): 511-522

53. Yang CL, Tseng CH, Chen YL, Lu CM, Kao CL, Wu MH, Tzeng CC (2010) Identification of benzofuro[2,3-b]quinoline derivatives as a new class of antituberculosis agents. Eur J Med Chem 45:602607

54. Kouznetsov VV, Ruíza FAJ, Méndeza LYV, Gupta MP (2012) Simple C-2-substituted quinolines and their anticancer activity. Lett Drug Des Discov 9:680-686

55. Supong K, Thawai C, Supothina S, Auncharoen P, Pittayakhajonwut P (2016) Antimicrobial and anti-oxidant activities of quinoline alkaloids from Pseudomonas aeruginosa BCC76810. Phytochem Lett 17:100-106

56. Lewis RE (2011) Current concepts in antifungal pharmacology. Mayo Clin Proc 86:805-817

57. Ashbee HR, Barnes RA, Johnson EM, Richardson MD, Gorton R, Hope WW (2014) Therapeutic drug monitoring (TDM) of antifungal agents: guidelines from the British Society for Medical Mycology. J Antimicrob Chemother 69:1162-1176

58. Choudhary NS, Kotecha H, Saraf N, Gautam D, Saigal S (2014) Terbinafine induced liver injury: a case report. J Clin Exp Hepatol 4:264-265

59. Folk A, Cotoraci C, Balta C, Suciu M, Herman H, Boldura OA, Dinescu S, Paiusan L, Ardelean A, Hermenean A (2016) Evaluation of hepatotoxicity with treatment doses of flucytosine and amphotericin-B for invasive fungal infections. Biomed Res Int:2016

60. Uno F, Tanaka J, Ueda M, Nagai M, Fukumuro M, Natsume M, Oba M, Akahori A, Masumori S, Takami S, Wako Y, Kawasako K, Kougo Y, Ohyama W, Narumi K, Fujiishi Y, Okada E, Hayashi M (2015) Repeated-dose liver and gastrointestinal tract micronucleus assays for quinoline in rats. Mutat Res Genet Toxicol Environ Mutagen 780-781:51-55

61. Suzuki T, Takeshita K, Saeki K, Kadoi M, Hayashi M, Sofuni T (2007) Clastogenicity of quinoline and monofluorinated quinolines in chinese hamster lung cells. J Health Sci 53:325-328

62. Yuzbasioglu D, Unal F, Yılmaz S, Aksoy H, Celik M (2008) Genotoxicity testing of fluconazole in vivo and in vitro. Mutat Res 649:155-160

63. Kolachana P, Smith MT (1994) Induction of kinetochore-positive micronuclei in human lymphocytes by the anti-fungal drug griseofulvin. Mutat Res 322:151-159

64. Doke SK, Dhawale SC (2015) Alternatives to animal testing: a review. Saudi Pharm J 23:223-229

65. Verma R, Vasudevan B, Pragasam V (2013) Severe cutaneous adverse drug reactions. Med J Armed Forces India 69:375-383

66. Pinheiro VA, Serikaku D, Baby AR, Velasco MVR, Kaneko TM, Consiglieri VO (2013) Development of ciclopirox olamine topical formulations: evaluation of drug release, penetration and cutaneous retention. Pharm Dev Technol 20:197-203

Publisher's note Springer Nature remains neutral with regard to jurisdictional claims in published maps and institutional affiliations. 